\title{
第41回 岡山大学医学部神経精神科臨床集談会抄録
}

\author{
日 時：昭和 52 年 12 月 17 日 \\ 場 所：岡山大学医学部図書館 3 階 \\ 主 催：大月三郎教授
}

(昭和53年 3 月20日受稿)

\section{1）精神神経科領域における「肩こり」 一一外来患者を対象としたアンケート調查}

杉原雅子 青木省三 池田 久男 (岡山大学神経精神科)

「肩こり」は，頭痛と同じくらい一般的によく耳に する訴えでありますが，頭痛に比べて，はるかに系 統的な研究が少なく，医療にたずさわる者自身，無 関心な一面を持っています。

そこで今回，精神神経科領域における肩こりの実 態調查をいたしましたので，その結果を報告します。

報告の基礎となったデータは，本年 9 月 1 ケ月間 に，岡大精神科外来を受診した精神病患者全員 387 名のフンケート調査によるものです。

\section{2 ）往診による在宅医療の試み}

最近, 病院の治療活動の中に，収容を前提としな い往診や訲門活動が組み込まれて来ているが, 当院 での実態を50年 4 月から52年11月の期間内で調べて みた。

対象者は58名（男子29名，女子29名）で，訪門理 由別にみると， 1 受診拒否 $\cdots 18$ 名，2. 治療中断 $\cdots 6$ 名，3.危機的状況...34名であり，成果を上げ得たと 思われるのは35名であった。特に危機的状況，治療 中断の理由に限ると, 40 名29名となり，アフターケ
それによりますと, 広義の神経症群においては， $57.8 \% か ゙$ 肩こりを訴え，その中でも筋祭張性頭痛75 \%，心身症 $71.4 \%$ が特に高い割合を示しております。 それに比べて精神分裂症が $28.8 \%$ という比較的低い 割合を示していることも倶味深いことです.

以上の様なことから, 精神病患者と肩こりとの関 連性について検討した結果, 肩こりが密接な関係を 持つという結論を報告させていただきます．

藤田 健 三 (県立岡山病院)

ア機能としての往診の有効性が示された。

又, 受診拒否者の場合, 往診の成否には, 家族の 関わりが重要である事が示唆された.

治療者の感想として, 往診の肯定的な面としては, (1)患者，家族に与える安心感，(2)治療関係が深まる. (3)タイムリーな関わりを可能とする. (4)生活状況の 把握，(5)保健婦との協力などがあげられ，問題点と しては，(1)時間的制約, (2)自閉症改善の困難, (3)入 院時期の判断の苦しさなどがあげられた。

\section{3）岡山県におけるアルコール症入院患者調査（そのI）}

堀井茂男洲脇宽池田久男 (岡山大学精神神経科)

大月 三郎 
けて行ない，第I次調查結果として，アルコール症 入院患者実態について報告した。調查病院の総病床 数は 4,591 床，入院患者総数は 4,499 名であり，男 2,558 名，女 1,941 名であった。うちアルコール症 者は, 257 名で総入院患者の $5.6 \%$ \%せていた．女 性アルコール症入院患者は25名, アルコール症者の $9.7 \%$ \% 一時点での調査ではあるが, 予想より高 い值を示していた。また，一年以上入院の長期入院
患者がアルコール症入院患者の41.6\%（107 名）を しめ, アルコール症者の治療の困難さを示唆してい るが，年間の統計をとると率の低下が考えられ，又 合併症等第 II 次調査の考察を待たねばならない。な お，フルコール症入院患者の平均年令は50才（21 89才）女性平均は46才，長期入院者では55才（35～ 89才）であった。

\section{4 ）精神症状と EEG-spike がシーソー現象をみせた興味ある一例}

中口
細川 欽 $^{\times}$清 $x \times$
向陽台病院 $x$
岡大神経精神科 $x \times$

症例：26才，男性，2 傾より痙縣発作を来たす ようになった。13才頃より抗てんかん都の投与を受 け出した。17才頃と19才から20才にかけて精神症状 のため某病院に入院歷あり。昭和 48 年, 22 才の時当 科入院したが，自開無為，独語空笑を中核とした精 神病状態を呈し分裂病に酷似していた。病象の完成, 寞解は比較的速やかであった。一周期は比較的長く， 観察した 4 年強の期間に二度発現し，各々，約 2 年,

1 年半であった.

精神症状寛解期には脳波上で中心脳性の両側同期 性の棘徐波結合を観察した。しかし，精神病状態に おいては，刺徐波結合は観察されなかった。

本例は Landolf の言う forced normalization に 類似の現象と考えられる。しかし，䊂徐波結合の消 長と分裂病称病像の逆相関であり，特異をもののよ うに思われる。

\section{5）いわゆる天才白疾 (Idit savant)の一例}

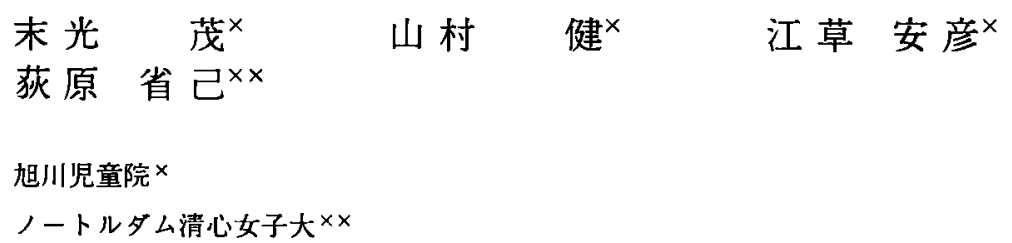

古来, 知能の全般的低下にもかかわらず，ある一 部の技能や芸術（とくに絵画や音楽）の面で秀いで た能力を示すものを天才白痴（Idiot savant）とい うが，卓越した音楽能力を有する23才，IQ30，男 の重度精神薄弱の一症例を経験した。

何ら特別の音楽教育をうけることなく，独習でか なり高度のピアノ演奏能力を有し，暗譜で演奏可能

\section{6) 昏迷状態について一患者の告白}

症例は20才の主婦で, 第 1 子出産後, 徐々に自発
な曲目は 100 曲をこえる，それらは 2 亿度の聴取 のみで演奏し，変調も可能である.

音楽環境を中心にした成長過程と音楽能力の現状 を報告し，あわせて他の精神薄弱および健常児・者 との比較検討を加え, 正常成人以上の正確なテンポ 感を保持していることを明らかにした。

\section{岩井闊之（川崎医大精神科）}

的行為がみられなくなり，約 1 週間後より昏迷状態 
に陥りました

さて，昏迷状態に関しては，心理的に説明された り，器質論的に説明されたりして，確定的ではあり ません.

今回は，患者の告白を中心にして，心理的側面か ら，昏迷状㮩について考察しました。

即ち，患者の夫と，Fさんという女性との仲につ
いて，患者は邪推・䃚妬したのですが，その事に関 して、問いただすことができない」という気持と， 「問いただしてはいけない」という相反する葛藤の 中で, 彼女は行為しないという不安を避けるための 唯一の手段一昏迷一をとらざるを得なかったと理解 し,・一方, Ambitendeng からの解放によって, 昏 迷を解いたと推測してみました。

\section{7）視線恐怖を伴った Anorexia nervosa}

両親との信頼関係をもつことが出来ず幼時期ひき こもりと空想傾向の強かった本症例は中 3 頃から自 己視線恐怖を自党していた。高 2 頃受験㔚強・友人 への美望・母との葛藤を機として Anorexia が発症 した．治療により「友達への㷕望の裹には暗い自分 への嫌悪があった，その自分は小さい時からの母の イメージからとり入れられたものであり母を憎んだ。 母を責める自分に母と同じ欠点をみつけ恥ずかしい.」 との洞察が得られ，それと共に身体症状の著しい好 転が得られた。

その後約 8 年の経過中視線恐怖が再燃し，一時的 には斜視手術を受けて斜視がなくなると視線恐怖の 根拠を失い「体が㞦る」という体感幻賞の発展も

\section{古元 順子 (岡大三朝分院)}

みられた。これらは莧物に反応せず，精神療法も中 断された。たまたま見合に「どうせ䭾目だ」と構え ないで臨み，却って好結果が得られた，劣等感が軽 減し，信頼する柤父との間で更に視線を合せる試み がとられた．視返す者のあたたかさが感じとられ， 以来他の人々との間でも視線を合せる自信が急速に 回復している.

視線恐怖は自己と他者との区別や，自己に関する 感情体験に関して自我境界或いは同一性の障害であ るといわれる。本症例の病態も根元的には自我境界 の障害と考えられ, Anorexia は思春期の成熟変化 に際しての危機を回避すべく発現したと考えられる。

\section{8 ) Perlapine (Hypnodin ${ }^{\circledR}$ )による薬疹の 1 例}

枝松 一 安 $\times$ 江原 嵩 $\times x$ 稲田 正 美
田
福山仁風荘病院
岡大神経精神科 $\times x$

Perlapineは睡眠凪として臨床的評価の確立され た薬郕であるが,他の多くの睡眠郕と異なり,Major Tranguilizer 類似の構造式を有している. そこで， われわれは抗精神病作用を期待して精神分裂病患者 にPerlapine を比較的大量を使用してみたところ， そのうち 1 例に重篤なアレルギー性薬疹を経驗した。 症例は33才男性, 破瓜熙張型分裂病. Halopridol $9 \mathrm{mg}$ 日の投与に加え, Perlapine 12.5mg日を投与し
た．10日目より皘部，下腹部，大腿内側部に灼熱感， 癌洋感の強い紅斑，水疮形成からビラン状を呈する 重篤な皮膚症状が発現した。.Perlapine 中止と対症 的処置により皮症状は急速に消腿した，現在のと ころPerlapineによる薬疹の報告は極めて少いが, 類似の三環系薬剤においては多数の薬将報告例がみ られるところから，Perlapineによる薬疹の可能性 にも留意する必要があると考えた。

\section{9）抗うつ剤による特長ある中毒症状を呈した 1 例 GB94との関係について——}

江原 峪 洲脇 寛 瀬 能 孝 敏 (岡山大学医学部精神神経科)


1072

$$
\text { 池田久男大月三郎 }
$$

45才時よりうつ病相と軽躁病相を反復する慢性難 治性躁うつ病の56才の女性が，G B 94の中断及び抗 うつ绪などへの急激な変薬の後に急激な意識障害な どを含む重症中毒状態に陥った，即ち, Chlorimipramine $100 \mathrm{mg}$, Carbamazepine $400 \mathrm{mg}$, Liothyromine $50 \mu \mathrm{g}$ の約 2 年間の服用の後, G B $9440 \mathrm{mg}$ 3 日間の併用に続き，G B $9460 \mathrm{mg} 4$ 日間単独服用を 行い, 続いて前記抗うつ郕に急激に変薬したところ, 翌日より意識混濁, 充鹪, 不安のせん妄状態とChoreoathefose, myoclonus, 顔面, 口唇の dystonie
などの不随意運動, 発汗, 高血圧, 頻脈などの交感 神経興䔀状態に陥った. Lovome promazine 12.5 $-37.5 \mathrm{mg} /$ 日と大皇補液により，約 8 日間で全ての 症状は消失した。これら一群の症候群は, 高アドレ ナリン, 低コリン, 高ドーパミン状態と解釈でき, このような中枢アミン不安定状態を引き起こした原 因として，G B 94のアドレナリン分泌元進，三環抗 うつ剂の抗コリン，アドレナリン再取入抑制，甲状 腺剤による Receptor の感受性立進などが原因にな り得ると考察した。

\section{0）抗てんかん薬血中レベルの経日的変化}

\begin{tabular}{|c|c|c|c|}
\hline 潤一郎 $\times$ & 橋 & 茂 ${ }^{x}$ & 御 影 池道輔 ${ }^{x}$ \\
\hline 細 川 & 久 郷 & 敏 明 ${ }^{x \times}$ & 堀井 茂男 \\
\hline
\end{tabular}

積善病院 $x$

岡大神経精神科 $\times \times$

抗てんかん薬を長期間，同一薬量で規則的に服用 している患者において，その血中濃度が経時的に， どの様に変動するかを観察した報告は少ないように 思える．そこで我々は，抗てんかん薬を規則的に服 用している入院中の患者 24 名を対象として 5 日問連 続で毎朝10時に採血し，その血中濃度を測定した。 各薬戍（D.P.H，P.B， C. Z.P, P.M) 間に おいて，いずれの薬郕でも体重あたりの投与量と血

\section{1） R 1 Cysternography $の$ 経験}

$$
\begin{array}{lll}
\text { 好永 順二 } & \text { 森田 博方 } \\
\text { 三宅 一政 } & \text { 引地 明義 }
\end{array}
$$

S.52. 6 より 6 ケ月間で41例の経験をした。初老 期ないし老年期の痴呆患者を対象に，まずC Tで䍁 室拡大の有無と程度のスクリーニングを行い，中等 度以上の腷室拡大を示す症例に R` cysternography を施行した．その結果，41例中10例，24\%に交通性 水頭症の所見を得た。 C T で高度な媨室拡大があり,
中濃度は可成高い相関が認められた。D.P.Hにつ いては，投与量が宮本らの言う $4 \mathrm{mg} / \mathrm{kg} /$ 日以上で 血中濃度が急上昇することが観察された．又どの薬 郕においても血中濃度が高レベルにある群は低レベ ルの群に比べ経日的変動が大きく，逆に低レベルの 群は経日的に安定していることが観察された．今後 は，より長期間にわたる抗てんかん薬血中レベルの 変動についての観察が必要と思われる。

\section{佐々木 高 伸 （広島市民病院神経科）}

かつ腷溝拡大を認めない症例で交通性水頭症のpattern を示す傾向があった. 初老期痴呆 2 例と正常圧 水頭症 2 例をあげて， C T 像と対応させながら R1 cysternography の所見を述へ，同時に痴呆患者群 に対するこれら二つの検査の使用意義を強調した。 